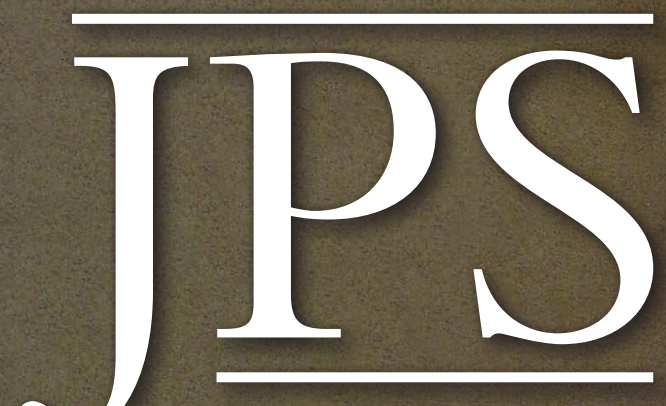

The Journal
of the

Polynesian Society

VOLUME 126 No.2 JUNE 2017

THE POLYNESIAN SOCIETY THE UNIVERSITY OF AUCKLAND NEW ZEALAND
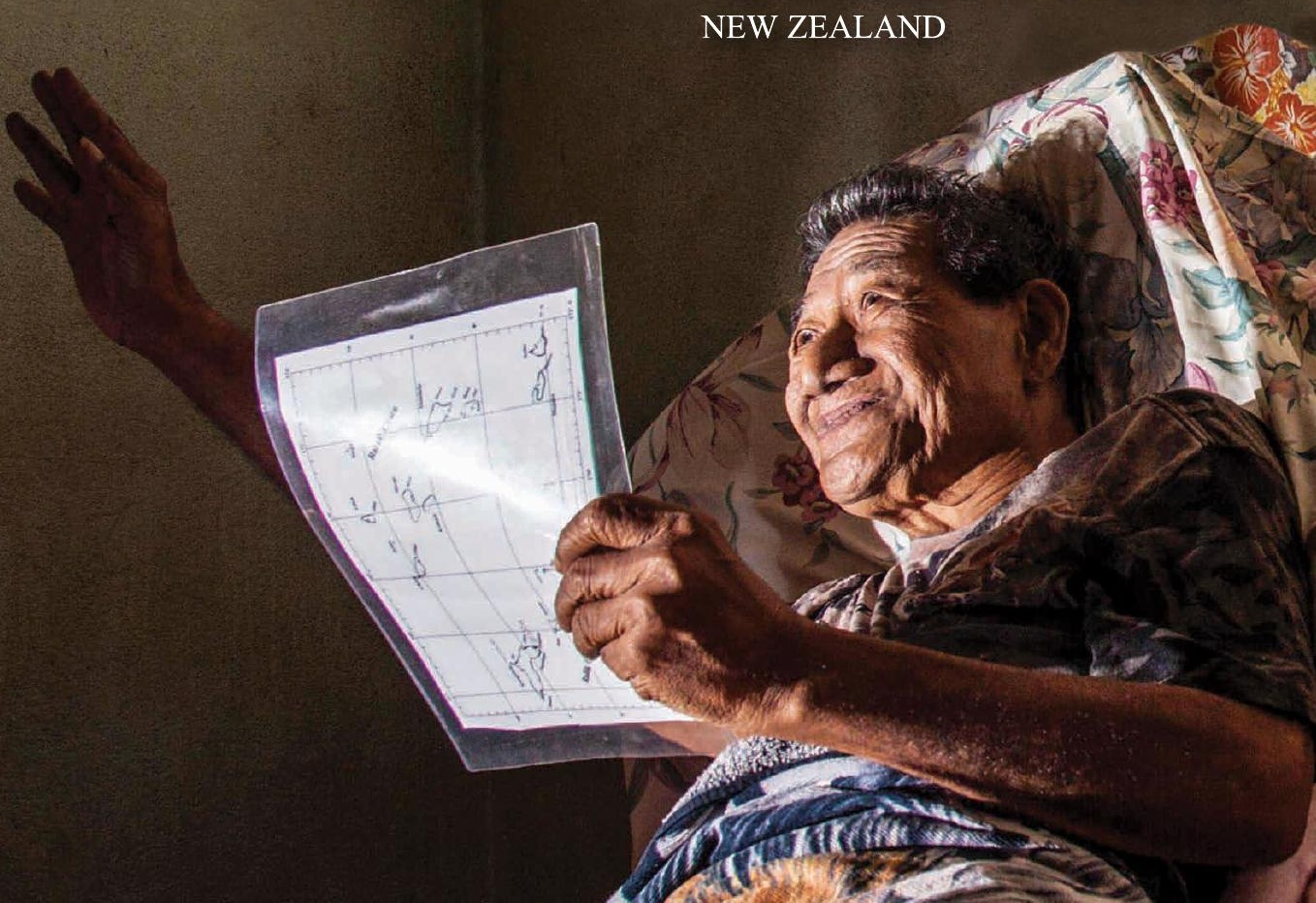


\title{
"WE DIE FOR KULA"-AN OBJECT-CENTRED VIEW OF MOTIVATIONS AND STRATEGIES IN GIFT EXCHANGE
}

\author{
SUSANNE KUEHLING \\ University of Regina
}

In 1993, during my doctoral field research on Dobu Island in southeastern Papua New Guinea, in a region often referred to as "The Massim", I accompanied my local mentor from Dobu Island, Joseph, ${ }^{1}$ on a kula expedition to Bwaiowa, on East Fergusson Island. We spent an afternoon on the veranda of his kula partner, while his wife was busy preparing our food. Since I was already into my second year of fieldwork, fluent in the Dobu language, and well aware that I was privileged to witness this confidential conversation, I listened attentively while chewing betel nuts and taking notes.

After some friendly exchange of standard information, about the state of gardening, the weather, and the valuable mwali ornament that our host was showing us, Joseph asked a question about their partner in the Trobriands. "How is Peter?" Our host responded "Ah, he is already getting weak". "Oh, good!" said my mentor, and our host uttered an agreeing sound. I was perplexed. Why would it be "good" if a partner further up the chain was getting weak, probably on the verge of death? How could these friendly old men be so matter-of-fact, even seemingly pleased, about this? (Extract from field notes, 17 October 1993)

For almost a century, the Kula Exchange System, involving the exchange of valuables in Southeastern Papua New Guinea, has been famous in Anthropology as an example of gift exchange with delayed reciprocity, built on trusting relationships of partners between some 20 islands that are part of the of the Massim region (Malinowski 1920,1922; Mauss 1990 [1923-24]). Hundreds of texts and museum objects are documented (Macintyre 1983a). A recent internet search yielded thousands of sources based on a handful of ethnographies from the northern kula region, specifically research on Woodlark (Muyuw) Island by Frederick Damon, Gawa Island by Nancy Munn and the Trobriand Islands by Shirley Campbell, Bronislaw Malinowski and Annette Weiner. ${ }^{2}$ Two conferences have contributed to a comparative perspective of kula (see Leach and Leach 1983, and subsequently Damon and Wagner 1989). Apart from these two volumes, the southeastern kula regions are under-represented in the comparative literature because Martha Macintyre's (1983b) and Carl Thune's (1980) excellent $\mathrm{PhD}$ theses remain unpublished (see Kuehling 2012: 23). 

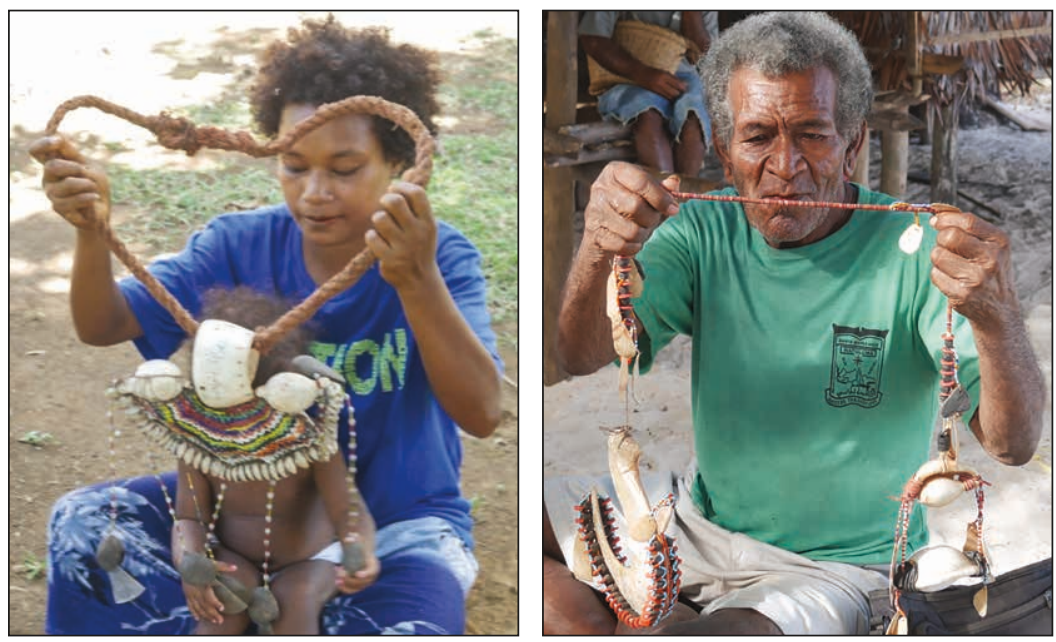

Figure 1. Mwali and bagi. Photos by the research team.

The aim of this paper is to offer new research material from the Dobuspeaking area of the southern kula region and Dobu language terms are used throughout unless otherwise indicated. My focus is on the two ornaments used for kula exchange today, mwali and bagi. Mwali, white sections cut from Conus shells, are often referred to as armbands. ${ }^{3}$ The necklaces, which are called bagi in the southern kula region, are made from strings of fine red discs crafted from the inside layer of Chama ${ }^{4}$ oyster shells. For kula exchange, both bagi and mwali are elaborately decorated with glass beads, shells, black banana seeds and other available materials.

The material side of kula exchange, mwali and bagi as a category of valuables ('une or kune; see Kuehling 2005: 98-113) provides an answer to the old anthropological question of how and why kula objects circulate-and continue to move today-in the Massim region. In this article I represent the voices, experiences, reflections and opinions of kula participants (or "players" as they say in English), which I was privileged to hear and share during fieldwork on Dobu Island and while on kula visits with neighbouring kula communities of East Fergusson Island (Bwaiowa) and North Normanby Island (Duau) (1992-94, 1997, 2009, 2012, 2015; see Kuehling 2005: 184).

Based on this research, I posit that it is the connection of bagi and mwali to life and death that causes the islanders of the kula network to be resilient in maintaining their unique and complex exchange system until now. The 
special value of kula shells is constructed in emotional and personal terms and the desire for bagi and mwali is a morally appropriate opportunity for demonstrating paisewa 'hard work' (see Kuehling 2005: 27, 281-83). I have previously argued that the importance of kula ornaments goes beyond what Reo Fortune called a "love for exchange" which, as he argued in Sorcerers of Dobu (1932: 193, 205-06), drove the voyages and interactions of kula among Dobuans (Kuehling 2005: 87). To give Fortune some credit, kula relationships (between pairs of partners as well as between pairs of objects) are often likened to love relationships: they are delightful and desirable yet difficult to maintain, fraught with conflict and betrayal, requiring hard work and affected by the uncertainties of life and death (Kuehling 2005: 182-224, 2012).

I begin by briefly discussing previous kula analyses that address the importance of history, memory and names as markers of value. I will then focus on the current generation of kula masters and their pragmatic perspective that kula valuables are crucial for "solving problems": in building, repairing and maintaining relationships both within island communities and between kula partners on different islands. Fred Damon (1983a) and Nancy Munn (1990) have published articles that use a single kula object for related arguments, although these accounts present kula exchange as causing rather than solving problems. I will refrain from deeper analysis of spatiotemporality (Munn 1986) and related concepts of personhood (Damon 2002), as my interlocutors were not thinking about their kula activities in these terms. While it is certainly possible that "through the stored bits of persons that are the ranked valuables, people convert their bodies into names realized in others' knowledge of them" (Damon 2002: 130), none of the kula practitioners in the southern Massim region who I talked to would describe it this way. The literature on Massim valuables cannot be done justice in this short paper but most recently, John Liep's (2007) monograph on Rossel Island valuables emphasised that personalised exchange does not mean partners are on equal footing and that transactions may be messy as "social obligation and personal pressure influence the decision of agents in exchange" (p. 18). While this is certainly the case in kula partnerships, the moral obligation of generosity and the mutual desire of kula partners to maintain a safe track for their valuables have strongly factored in, keeping the kula moving until this day.

I was told many times that the value of all kula objects as a category, together with the other two major items of exchange (pigs and yams), stems from their symbolic power to compensate a person's work and commitment, suffering and grief, in short, their capacity to solve local conflicts, fulfil obligations and to provide food in times of need. This is why the most capable islanders are involved in kula, distributing large amounts of their garden 
produce, providing a shelter for relative strangers in the hopes of receiving kula objects in the future, braving the seas on their travels to visit partners, teaching their smartest children the rules and magic, names and tricks of the trade, enduring the envy of their neighbours, and dealing with the demands of their elders. Kula is a valuable activity because its objects are endowed with the "spirit of generosity and hospitality" (Trevor Timoti, from Dobu, pers. comm. March 2016). For more junior participants in kula, its capacity to provide quality time away from the village, and to give an extra purpose to life are a bonus, but the main incentive to engage in kula is the knowledge that bagi and mwali are needed because "we love, marry, fight, get sick, and, ultimately, die" (Kaibado Joel, from Dobu, pers. comm. December 1993).

\section{HEIRLOOMS AND THE QUESTION OF NAMES}

The famous anthropologist Bronislaw Malinowski told us in his classic study of kula exchange, Argonauts of the Western Pacific, that the value of kula objects is based on their history, much like European heirlooms:

The analogy between the European and the Trobriand vaygu' $a$ (valuables) must be delimited with more precision. The Crown Jewels, in fact, any heirlooms too valuable and too cumbersome to be worn, represent the same type as vaygu' $a$ in that they are merely possessed for the sake of possession itself, and the ownership of them with the ensuing renown is the main source of their value. Also both heirlooms and vaygu ' $a$ are cherished because of the historical sentiment which surrounds them. (Malinowski 1922: 89)

Ever since, most anthropologists have accepted this statement. Fred Damon, however, based on his field research on Woodlark (Muyuw) Island, learned that physical size, rather than transactional histories creates the value:

[...] in the legacy of Bronislaw Malinowski, which the most recent ethnographers reproduced (e.g., Campbell 1983a, 1983b), kula valuables gained in stature or prestige as they accumulated history, through their travels around the islands. But this is not what my informants said. For them the ranks for valuables were more or less fixed by the sizes they had when they were produced. (Damon 2002: 114)

Indeed, according to my informants from Dobu, size matters. The transactional history however determines the highest ranks of valuables, those with a well-known name. About 100 famous names would be in the repertoire of most kula masters, and of these only 30 or so are regarded as the highest-ranking ornaments of kula exchange, paired in "married couples" of bagi and $m w a l i^{5}$, passed around on relatively stable routes between people 
of the same, or matching clans. While their value is based on more than "historic sentiment", details of their journeys around the exchange system are fragmentary and vague, as Damon learned on Woodlark. Similarly, Dobu kula players look at size and patina if they are not clear about the rank of a valuable. They count the circles (ulai) that bagi and mwali have successfully completed around the system and they recount the pairings that have successfully been made on these journeys, the persons and places that have seen the objects, as well as the errors and conflicts that affected their moves. For the top-ranking bagi named Teleiponi, for example, I learned that "at the first round it came to halfway and it hit Nanowana, the second hit it made was Atuidamana. So when it went around, it came to Wale-anaduudu, it met Youya, it met Bwaluwada, and it came back to Atuidamana and is with Atuidamana now" (Synod Timoti, from Normanby Island, pers. comm., February 2016).

Knowing such "histories" (tetela) is like knowing the story (also tetela) of a plot of land or the ancestresses of a matrilineage - it counts as proof of legitimate ownership. Tetela are consequently not told in public settings unless required in a mediation or court case, and only by authorised members of such an object's route around their ring of partners. I was nevertheless privileged to record Mr. Synod Timoti's tetela of the bagi Teleiponi, which begins as follows:

This is the story about Teleiponi, where it comes from and why it came. The original name of Teleiponi [telephone] is Waialesi [wireless]. One of our bubus [grandparents], his name is "KW" [pseudonym, here and below]. He lives at Ware Island and he got married there, a village called "G". He had many children, about twelve, so when he was there and he grew old, the children decided to give us that bagi for their pwaoli [compensatory gift to the father's matrilineage], and we call it pwaoli kalakalawa because the old man is still alive but they want to pay pwaoli. So, our bubu, mother's father, by the name of "LK" and our mother, "SP", from our place went to Ware to visit the family there, that's where they presented the bagi to our bubu and brought it to Duau to our place at "M" [on the Duau coast of Normanby Island]. So when it was there, our bubu was still keeping the bagi, in the kula ring they heard that mwali Nanowana is with "M" at "D" [Woodlark Island]. And that was his kitomwa [free-of-debt kula valuable]. So our old people from Dobu decided to come to our bubu and get this bagi so they can get Nanowana.

To understand such stories, a complex set of background knowledge is needed: of persons, places, and the top-ranking mwali and bagi. Most kula masters would generally agree on the list below that features some of the best-known kula objects. 
Table 1. Names of highest-ranking bagi and their mwali "spouses", as known in Dobu. Italics indicate undisputed partnerships.

\begin{tabular}{|ll|}
\hline Bagi & Mwali \\
\hline Dilimeya Tubetube & Tukava (or Tamagwali) \\
Dilimeyana 40 & Tomanuboi \\
Kasabwaibwaileta & Kepou \\
Kasanaibeubeu & Manuatasopi \\
Likudomdom & Waleya ana duu (or Nanowana) \\
Senibeta & Bwaluwada \\
Teleiponi & Atuidamana (but according to tetela cited above, \\
Tukanibwalala & it should be Nanowana, its first "marriage partner") \\
Tukawa & Bwaluwada \\
Bagiduudu & Kabwaku Tamagwali \\
Dokanikani & Kepou \\
Gomalakedakeda & Inimoa (or Tomanugwali Tumanuboi, also Wabaleki) \\
Kibutokunuwesi & $?$ \\
Lepoyata 1 & No specific "spouse" yet \\
Malalana & Youya \\
Meiya & Tomanugwali Tomanuboi \\
Senibeta 2 & Tokulasi \\
& Kebulubulu (or Bwaluwada) \\
\hline
\end{tabular}

Table 2. Names of some second-ranked bagi and their mwali "spouses".

\begin{tabular}{|ll|}
\hline Bagi & Mwali \\
\hline Magisubu & Kabisawali \\
Tokanibwalala & Maikala (or Tokana) \\
Anoibutuna & Ulilaba \\
Bagidudu & No specific "spouse" \\
Siga & No specific "spouse" \\
Mwalubikina & No specific "spouse" \\
Lala & No specific "spouse" \\
\hline
\end{tabular}


These lists are neither complete nor do they represent total consensus; only the pairs in italics are undisputed as far as I know. The names have been spelled in different ways by locals and by anthropologists, adding to the complexity and occasional confusion. Yet whenever the ranking of kula objects was discussed, fragments of this list were reiterated by senior men, sometimes in the form of a rhetoric quiz: "Who is the spouse of Teleiponi? Atuidamana, of course!" As in a marriage, people say, things may go in wrong directions but "we try to bring them back to normal". Life cycle exchanges are an opportunity to readjust the tracks of kula valuables; mortuary rituals especially intersect with kula in complex ways (Damon and Wagner 1989). The top-ranking bagi and mwali are well-known and their ideal tracks are linked to a complementary one that moves into the opposite direction-until one of them is taken off its route and instead given to someone from a different matrilineage. This happens frequently, through patrilineal inheritance or as a gift for exceptional service, causing the partners on its ideal track to scheme and plot until the circulations are correctly realigned. This may take decades, as in the case of Kibutokunuwesi, a large mwali that has never completed a tour around the chain of partners.

The case of this mwali shows that value can be independent of a long history of exchange. In 1975, Kibutokunuwesi was found on a reef near Kiriwina named Kibu (which is also the name of a star) by a man named Tokunuwesi. He cut, named and decorated it before passing it on to his partner in the Amphlett Islands. The late maternal uncle of its current owner, from Bwaiowa (Fergusson Island), received it there and he has held onto it ever since, for 37 years now, waiting for a Dobu man to offer the appropriate bagi. Many have tried to lure Kibutokunuwesi into their hands, but so far no-one has achieved this goal. Some complain that their "begging" gifts of bagi that were supposed to "loosen" Kibutokunuwesi were not returned with matching mwali at all, so they suspect that the current owner is using the mwali to attract bagi by using Kibutokunuwesi as a lure, or bait. The man himself, on the other hand, complains that Dobu men are not capable of "hitting" his mwali properly. In spite of being blocked and even hidden, as only a few people have actually seen it, the mwali was being talked about in the 1990s when I was doing my doctoral fieldwork; it was still a topic of discussion in 2017 and many men's dream is to lay their hands on it. It has only been exchanged twice, the shell is scarred with rough grey marks, and yet it has a high value based on its physical qualities: the size of the Conus ring indicating its age. Kibu, its nickname, demonstrates Damon's (2002: 12) point that "the significance of these valuables is not that they carry sums of human memory".

High-profile bagi and mwali attract the most attention of kula masters and anthropologists, but there are hundreds of unnamed valuables that nevertheless fully qualify as kula wealth, in current circulation or in the hands of outsiders (individuals, art dealers and museums). These objects, mainly 


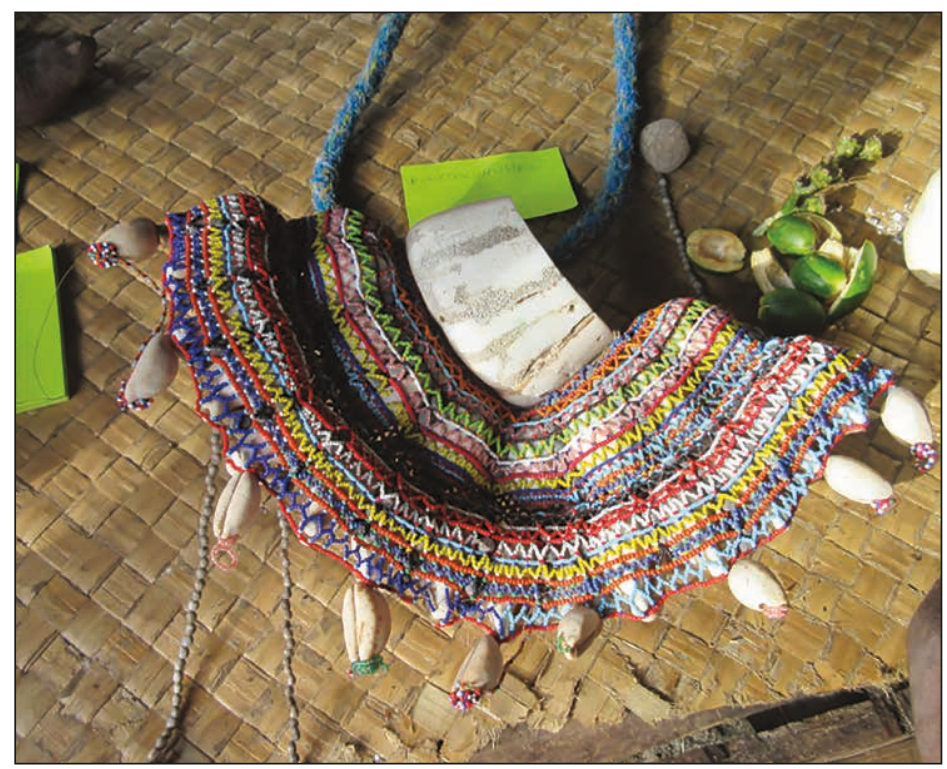

Figure 2. The mwali Kibutokunuwesi. Photo by the author. N.B. an older picture by Jutta Malnic (1998: 82) shows a different decoration.

smallish mwali, typically give no indication of names in the documenting files. Over 2000 valuables are named but not famous, their names known only to a few individuals. One medium-ranked mwali stored in the National Museum and Art Gallery of Papua New Guinea is exceptional because its name is documented. It was recently identified by a man from Dobu called Jones, who recognised it as his missing kitomwa (debt-free kula valuable). He claimed that he himself had written its name, Lepaudi, on the shell with a carpenter pencil, sent it on a kula track many years ago and had not seen it since. According to rumours, it was sold on Gawa Island, intended as a gift for Prime Minister Michael Somare. Being from the Sepik, however, and not sharing kula notions of value, he was not interested in it and it ended up in the National Museum in Port Moresby. If the name had not been written on the mwali, it is unlikely that this story would have emerged, but somebody had remembered the name and passed word on to Mr. Jones who then came to see the photograph I had taken of it. He cried when he recognised Lepaudi and asked me to help him get it back. So far, the Museum has not responded to my request. 

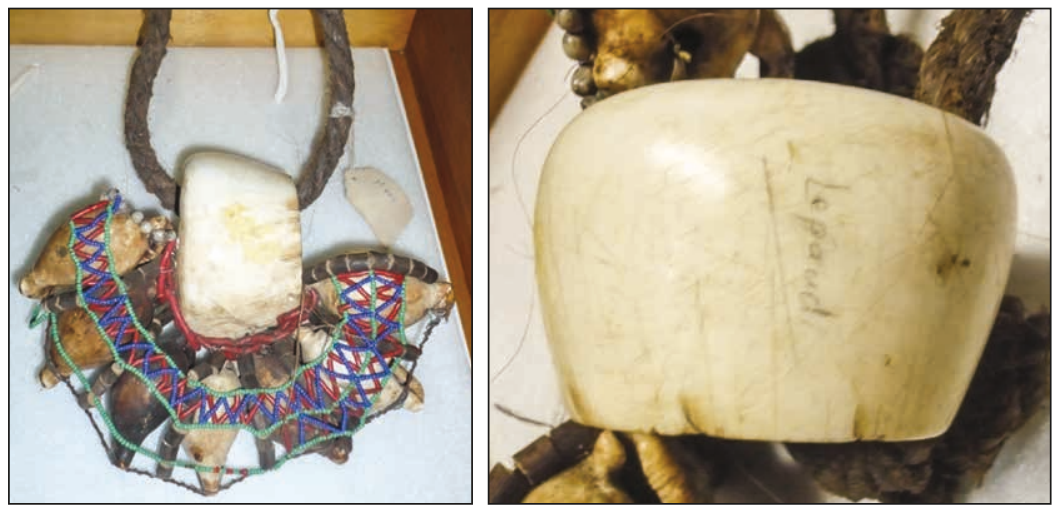

Figure 3. The mwali known as Lepaudi (Papua New Guinea National Museum \& Art Gallery accession number M401). Photo by the author.

The carefully crafted decorations, seen as the "face" of the objects, are not important for the ranking of kula objects. Damon states that "although intentionally and repeatedly adorned and redecorated, and momentary objects of fancied gaze wherever they alight, kula valuables do not become famous by these names and decorations" (2002: 125). Yet, while the meaning of a name is irrelevant for its value, they are convenient to identify and to recognise a valuable. When I showed images of old and obviously well-travelled kula valuables to Dobu kula men, their first question was always "What is its name?" If I did not know, people's interest in the object seemed to fade, as names serve as a mnemonic device, making it possible to talk about individual objects. Knowing these names is part of the specialist knowledge of kula as they distinguish specific bagi or mwali. The decorations can change without affecting the value and, except for famous ones, even a kula master cannot routinely tell one from another. Frequently, names are written on, or scratched into, mwali shells and the pearl-shell that is attached to a bagi string. However, these names do not necessarily refer to the object itself but temporary owners, serving as nametags that facilitate the valuables' redistribution. In the Dobuspeaking part of the kula network, this ceremony, called tanaleleya 'all the baskets are equal', should take place at the end of a group's kula expedition. The leader of the trip collects all the kula valuables and during a large and sumptuous meal that he sponsors, the valuables are hung up in a row (sola) and sorted according to rank. The most valuable ones are usually on the right-hand side and their value decreases until the least valuable one is on the far left (the order may also be reversed but the principle remains the same). 


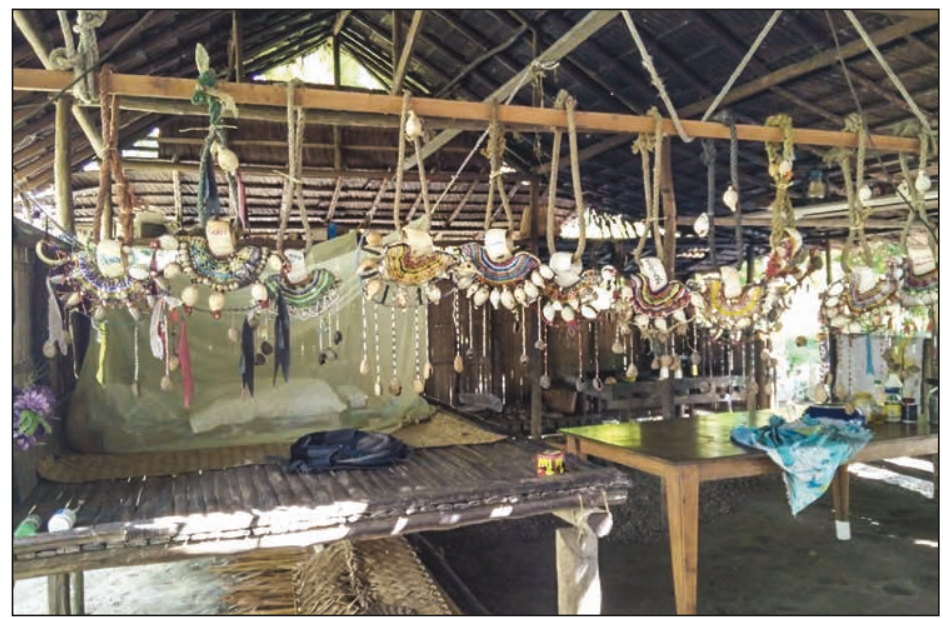

Figure 4. Tanaleleya with mwali at Sawa'edi, Fergusson Island, August 2015. Photo by author.

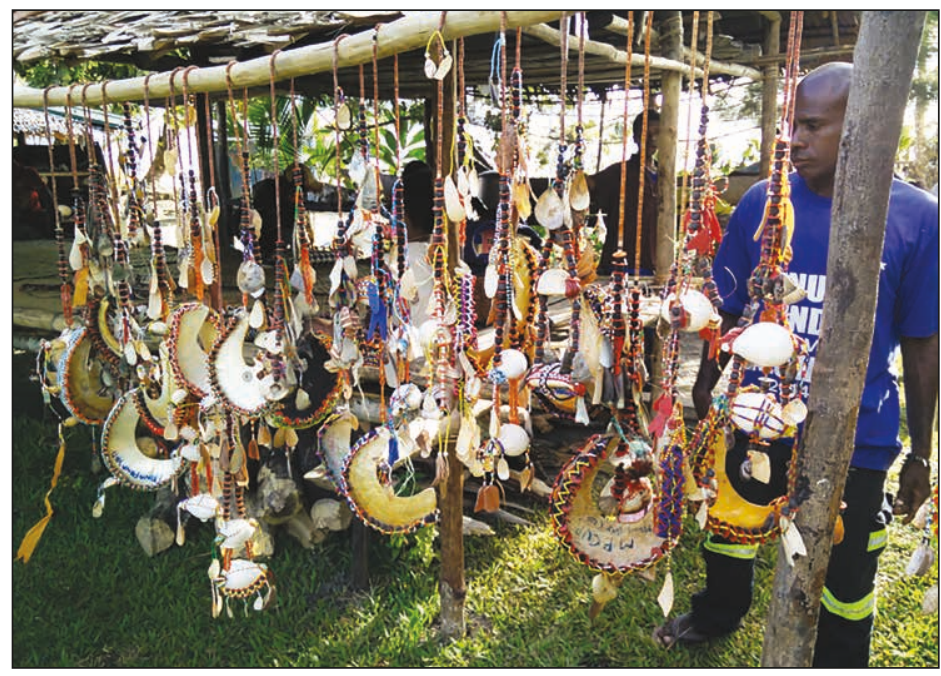

Figure 5. A row of bagi, not yet sorted by size at Asagamwana, Fergusson Island, August 2015. Photo by author. 
Those mwali and bagi of lower value, without an individual name, are used for exchanges of the highest order within island communities (mortuary feasting, bride wealth, compensation, purchase of pigs, etc.) as well as being passed on in kula exchange. Such kula valuables may be "low-ranking" in comparison to others, but all of them are nevertheless regarded as "Big Gifts" (Kuehling 2017; see also Kuehling, 2005: Chapter 4), to be used for special transactions, admired and treasured, in short, as objects "to die for" (Damon 1983a: 54; Kuehling 2005: 113; Munn 1990). Together with pigs and large yams, they are the most precious things worth striving for as they "solve problems" related to life and death. Sometimes the transactions do not turn out as expected and my informants claim that nowadays misunderstandings and "bad" choices are frequent, deeply aggravating the concerned parties and often triggering sorcery retaliations, causing a chain of deaths. Even if there is no intentional cheating, difficulties of assessment are common. As Damon has pointed out, names can be misleading. He mentions cases in which valuables are talked about so much that people expect them to be very large:

I also heard people tell what they thought were funny stories about certain valuables over which there was a lot of dispute. They imagined these disputes going off down projected paths, the peoples there hearing the stories, and then imagining that the valuables must really be big if they generated so much talk. (Damon 2002:114)

In addition to such stories, there are other challenges to the use of names as identifiers. Sometimes, a famous name tempts a kula trader to tinker with its value by removing the decorations and attaching them to a different object. In this way, two valuables are created, one is "old" but newly decorated, the other one is "new" but adorned with a famous "face" (see Kuehling 2005: 205).

A widely practiced form of deception is to name a low-value kula object after a famous one. In Dobu this is called esabala or literally 'passing a name across' (or the English-derived word beptais in the northern Massim). While documenting kula objects as part of our current research project, the local research team from Dobu Island was surprised to find so many cases of this practice. Mwali namesakes include those named Masisi (11 examples), Taba (six), Lala (six) and Gudala Ikaya (six); among the bagi, Kenoliya (ten), Wayau (eight) and Weibitu (nine) are circulating and causing confusion. Only one of each has the value of dagula, the highest ranking category, or bulubulu, the second grade category. The others are of lower value. Thus when discussing future exchanges, a kula player may promise to pass on the mwali Masisi, and keep his promise, while upsetting the recipient who expected a high-ranking valuable and only received a mediocre one. 

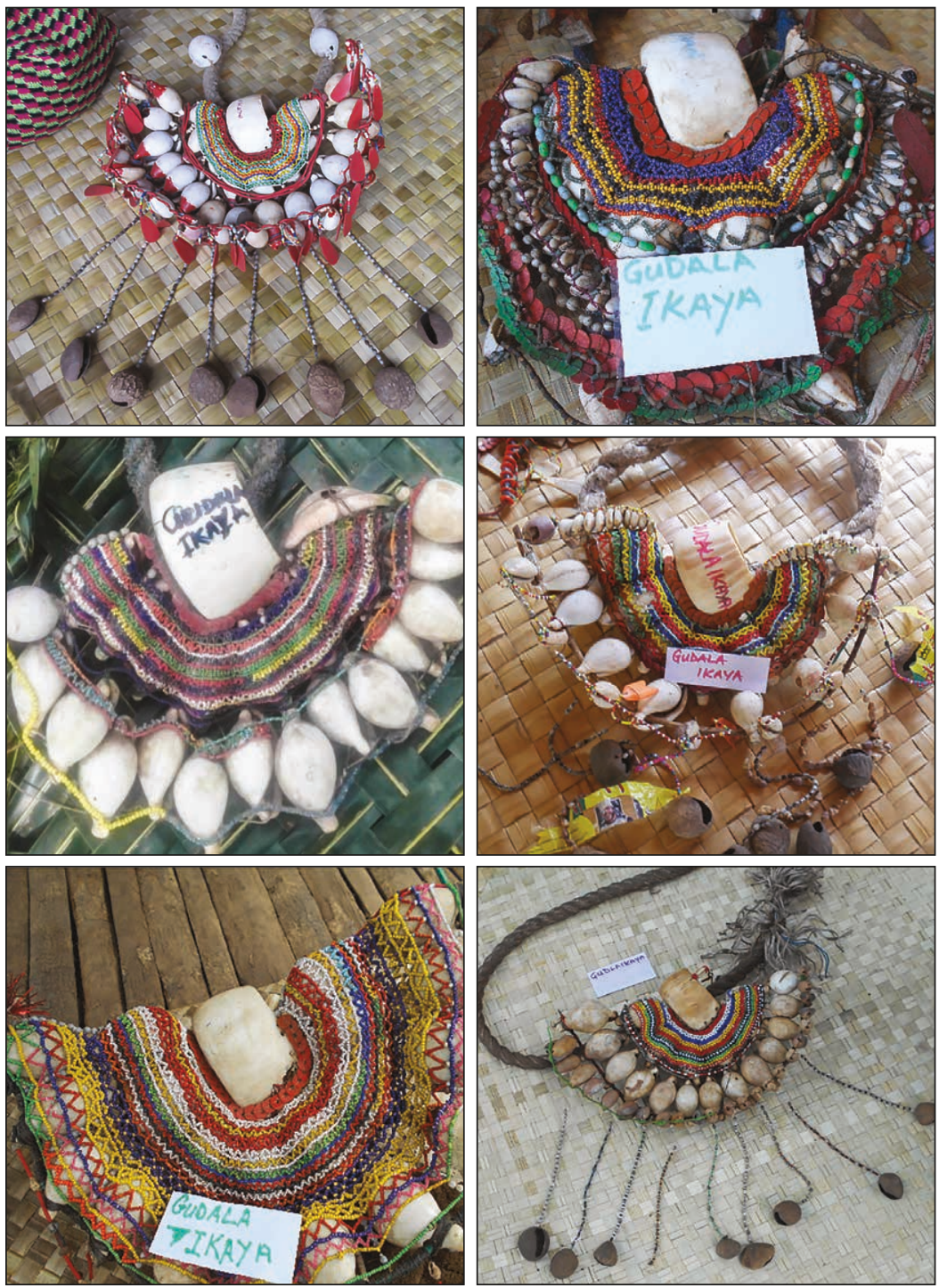

Figure 6. All six of these mwali are named Gudala Ikaya. Photos by research team, 2015 and 2016. 


\section{DEATH}

The statement that "people die for kula ornaments" was familiar to me when I undertook my fieldwork, as I had read the anthropological literature on kula prior to my departure. And yet, the conversation paraphrased at the beginning of this article was an eye-opener, as it helped me understand that death affects kula in complex ways. I initially believed the statement referred only to the fact that desire for the ornaments is so intense that people risk their lives on overseas journeys, and face the jealousy of their peers after achieving their goal of obtaining a specific bagi or mwali. Any senior kula participant will confirm that death guides kula exchange, a fact that is somewhat at variance with the more publicly voiced role of kula to "promote respect, love and friendship, hospitality, status and adventure" (Hon. Michael Wapanapa, Bwaiowa ward member, September 2015). By enquiring further, I began to realise that death and life are at the heart of kula and that the health status of partners is highly relevant in various ways.

The question "How is Peter?" in the conversation I quoted at the beginning, referred to the flow of mwali. Since Peter was a senior kula man, his death was going to halt kula exchange in one direction for a while. This blocking of exchange, called alau on Dobu, begins a few days after a death, when local elders decide on the direction that will be blocked (gatu or bubuli). Either mwali or bagi may reach but not leave the location, so they accumulate over a period of some months. Only when the neighbouring kula community on the other side of the blocked zone organises a group expedition (yawala) (further details in Kuehling 2005: Chapter 7), bringing gifts and assembling for a meeting where meals are consumed and speeches are made, is kula traffic opened again. As a consequence, a great number of valuables flood to the visitors. In Dobu this movement around the network is called ulai; one circle around the chain of partners, one ulai, takes at least three to five years. The blockage, usually represented by a pole in the sea near the shore with a broken conch shell or an unhusked coconut on top, is removed at this event and kula exchange is open again for individual visitors and small groups. During the opening ceremony, the heir of the dead kula player, ideally his sister's son, introduces himself and begins an exchange relationship, ideally with the orphaned partner, by passing a valuable. This is a good time to voice discontent about previous exchanges, to remind the new partner of the ethics of reciprocity, and to apologise if the deceased had left debts behind. Since these blockings occur all the way around the exchange system, a death can seriously affect the strategies of kula players.

Another event resulting from death in Dobu is the reintroduction of a principal mourner to kula exchange, the kwausa ritual. After the death of a 
kula master, a group of close relatives is kept in a state of passivity that is step-wise removed in a series of mortuary rituals ( $b w a b w a l e)$ until finally they can resume their ordinary lives (see Kuehling 2005: Chapter 8). Kula is one of the activities that requires formal reintroduction and the heir of the deceased is taken on a kula expedition (see Kuehling 2005: Chapter 7). In the past, the passive state of mourning often took several months, but nowadays people like to speed up the process, especially when the expedition is expected to move many valuables.

I witnessed such an event in September 2015. The Dobu man who came to Bwaiowa for the re-opening of kula, only ten days after the death of his maternal uncle, stood up and exclaimed: "My uncle did not tell me what had happened. He only told me I was his heir/replacement (loepaelu), so I am sorry but I don't know what went wrong between you two." Everyone in the audience had a good idea of what had actually happened; the dead man had failed to return at least one valuable in spite of his promise. Yet the hosting partner stood up and said "Let the old stories rest now, just make sure that we will have a good kula partnership. I will give you this mwali now, and next week we will come to you for bagi." He could have scolded or reprimanded the heir by recounting the flaws in his uncle's kula exchanges, because he was giving a mwali and such a "Big Gift" opens a window for accusing speeches. Yet by letting the opportunity pass, the partner signalled his benevolence and only hinted that when he was paying a return visit he did expect an appropriate counter-gift, preferably more than one, to compensate for the loss that had occurred in the past.

The question about Peter's health, therefore, related directly to the future of kula exchange in general-will there be a group expedition on the horizon? Will his designated heir take over soon? How will it affect our chain of partnerships? Will there be a blockage and subsequent flood of mwali in the near future? Damon (1983a) describes the art of plotting and scheming in his brilliant article on the history of Woodlark (Muyuw) Island.

The inquiry about Peter's health could also have referred to his conduct. Any death, as some people pointed out to me in private, may well have been directly caused by fraudulent kula practice, as sorcery attacks are still regarded as appropriate sanctions. Such suspicions are never expressed in public, however, and remain the subject of private conversations. When Peter's health status was discussed, it could have been an allusion to his punishment for previous mistakes in kula, inflicted by an angry kula partner, in this case, quite likely, our host. In the past, I was told, kula was much more seriously sanctioned: "six feet" (the metaphor for a grave) was the expected outcome of cheating, procrastinating or wrongful exchange of any kind.

Nowadays, there are committees (komitis) in many southern kula regions (on Sanalowa, Fergusson, Dobu and Normanby Islands) that are aimed at 
preventing such dire consequences. Based on the European model, komitis are elected by kula players of the locality, complete with a chairman, a secretary, a treasurer and a vice president. On Dobu Island, there are six such komitis (in Edugaula, Mwanomwanona, Enaiya, Egadoi, Wabuna and Balabala). They are supposed to mediate when wrongful exchanges cause anger, mistrust and envy. I witnessed a case in which the komiti on Dobu ordered a person to pass on a mwali to a specific partner, although he had planned on keeping the valuable as "village wealth", as it was free of debt. Komitis have succeeded in moving valuables between men within their jurisdiction; they have stopped and reversed exchanges and imposed fines as punishment, although in some cases they are unable to find out the "true" story and cannot come to a decision. The trust in komiti mediation is therefore limited and an aggravated kula partner may well take the law into his own hands and apply pressure. The first level of showing anger is usually to refuse any food prepared by the partner. If that does not yield results, he may secretly use a curse that causes sickness, disease or even death, depending on the degree of rage and the capabilities of both partners for either effectively cursing or successfully protecting oneself from a curse. Nancy Munn (1990) shows the difficulties of being involved in the exchange of high-ranking kula objects like the mwali Manutasopi on Gawa Island. I have heard comparable stories but prefer not to publish them here as they are regarded as confidential, upsetting and even offensive to participants and, sometimes, for bystanders.

In the present case, certain major kula men, speaking about their shell transactions, asserted their lack of interest in obtaining a well-known, highly valued armshell called Manutasopi that the patient had transacted in an irregular manner that year. These speakers could have been in competition for Manutasopi because each had a separate partnership with John, the Boagis islander who had decided to give the much desired shell to Silas and to the latter's exceptionally influential northern Kitavan partner. For instance, Thomas, a senior kula man and the most important witchfinder and curer on the island, pointed out that his own kula path (ked) with John was not one along which he could expect such high-standard shells as this one. Furthermore, he had warned Silas and the Kitavan not to make the irregular arrangement with John that allowed the shell both to bypass the Muyuw partner on their (Silas's, the Kitavan's and John's) common path and, in addition, to be taken immediately to Kitava without coming first to Gawa. People felt that Gawans might be angry, since having Manutasopi on the island would have contributed to the Gawan name in kula. (Munn 1990: 4)

In this way, the brief statement that "Peter is already weak" and the response "Good" did not indicate a lack of compassion per se, but needs to be understood as part of the scheming, planning and anticipating of kula 
exchanges of the future. The two Dobu-speaking men were working together on a long-term plan to strengthen their exchange relationship, as good kula players ought to do. A kula man's death, as we have seen so far, can be interpreted as justified punishment, as the result of his kula malpractices and can open the way for his heir to straighten out the route and create better relationships. Death, it follows, can take "crooks" out of the game and give others the chance for a new beginning.

As the death of a "big man" may result in a series of feasting events, the response that "Peter is already weak" could also have meant that his lineage would be likely to receive many valuables in due course. These would effectively enable Peter's heir to pay the debts that Peter had accumulated. This could also require Peter's kula partners to bring a valuable, but they could provide either type (bagi or mwali) for the purpose, as local exchanges do not follow the clockwise-anticlockwise routes that are an essential part of inter-island kula gifting practices.

The statement also could have indicated that there was a chance to secure mwali from his affinal relatives and his children before his actual death. Kula is an opportunity for hiding valuables from lineage obligations, especially for the more junior members. The senior lineage members of a man's in-laws and children are obliged to contribute to his mortuary feast, so when a death is likely to occur, younger kula participants of these lineages may be tempted to pass their valuables onto a kula path, rather than risk losing them to their seniors' pressing demands to contribute them to the mortuary gift. In kula, a counter-gift can be expected within a short period of time; a mortuary gift is not returned until the next death requires it. In addition, the lineage seniors who manage mortuary gifts may or may not return a valuable to its donor; they may simply keep it as their "village wealth", thereby depriving a junior kula player of opportunities for travel and adventure, complicating his aspirations and schemes, and even ruining his reputation if he is incapable of providing a return gift. It is disrespectful to demand such a gift back from one's lineage elder and I have heard many times how people lost their kula valuables due to local exchange obligations following the death of a father or in-law. "I could not ask for another valuable, it is too embarrassing" was the typical response when I asked why they did not claim a bagi or mwali when it arrived after a death in their own family. To complicate such a situation further, mortuary gifts require either bagi or mwali, while kula partners can only receive one kind, depending on their location (positioned either clockwise or anticlockwise).

So, as Joseph and his partner were exchanging information about their partner Peter's health status, and uttering satisfaction about his decline, they were really commenting on his qualities as a kula player (not very 


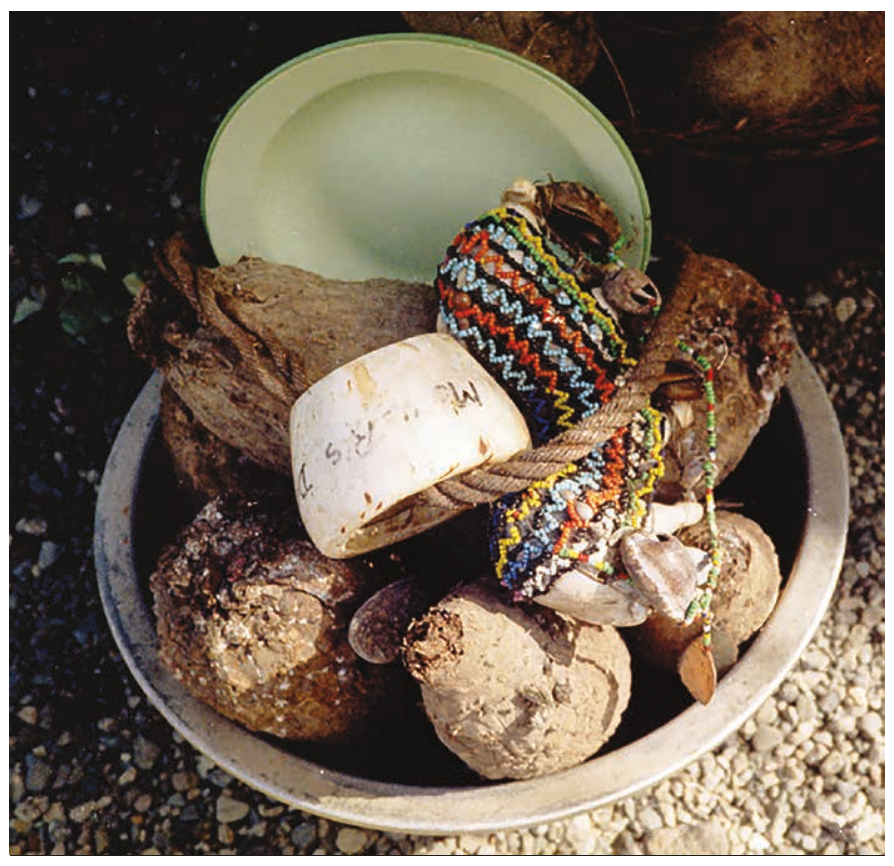

Figure 7. A mortuary gift (talo) on Dobu, June 1983. Photo by author.

satisfactory), the prospect of his heir's qualities (likely more positive), the expected consequences of his death for major kula events (bubuli ana so 'oalways exciting), and the resulting pulse that mortuary feasting triggers (which they could perhaps benefit from by avoiding the gift of a valuable or by luring mwali from his in-laws' or children's lineages). If Peter had been sick for a longer period of time, the woman who took care of him, typically his wife or one of her relatives, might have received a kula object to compensate her for her work. In this way, even highly valuable mwali and bagi can change their routes, crossing over to a different clan and complicating future exchanges.

Death, it follows, may impact the island community's exchange practice as a whole, by halting and then releasing the flow of valuables. This causes a pulse-like movement of valuables, brings about much excitement associated with group travel, feasting, oratory, reconciliation and re-creation of kula routes. The conversation between the two kula masters, as I have shown, was brief but highly relevant for their future exchanges. 


\section{LIFE}

Mortuary gifts are also about life as they reconnect lateral relatives, reinforce kinship networks and represent the lifetime of work, love and care of a deceased (see Damon and Wagner 1989; Kuehling 2005). The contingencies of death are not the only risk to the plans of kula partners; the value of kula objects is also closely associated with life and love between affinal relatives. These gifts often occur between clans within an island community. Such gifts, as in the mortuary rituals mentioned above, are not bound by any clockwise/ anticlockwise movements but by the idea of "Big Gifts"-assemblages of items such as bagi, mwali, large yams of specific types (cultivars known as uma in Dobu), pigs and decorative items, such as betel nuts, sugar cane, taro, banana bunches and store goods (Kuehling 2017: 231; see also Kuehling 2005: Chapter 4). A man's gift to his bride's matrilineage should contain at least one bagi or mwali, especially when the bride is beautiful, has no children as yet, and has demonstrated her skills in gardening and household duties. Today, a bride with an education (i.e., a nurse, school teacher or clerk) is regarded as a valuable asset and her parents can ask for a larger gift to acknowledge the money spent on her education, their sacrifice in raising the funds, and their loss of a worker in daily subsistence activities. Once she gives birth for the first time, the father of the child should give a bagi or mwali to her in a gift called gwama ana loduwaduwa, to acknowledge her pain and the risk she took in giving birth, "because blood was dripping". These gifts are a token of love and respect, and are evidence that the lives of the bride and baby are appreciated. Similarly, the gift for a deceased father, mentioned above, is an acknowledgement of his love and work for his children, for his wife's matrilineage and for her village in general.

Kula valuables can be given to "ask for" a plot of gardening land or permission to settle in a specific hamlet. They can pay for a canoe and, most importantly, they can acknowledge a gift of life-saving food. The story of the famous bagi named Dilimeyana may serve as an example. This is what I learned from Mr. Trevor Timoti, a Duau man and kula master, who currently lives on Dobu. The story begins sometime after World War II, when a severe drought challenged the people living on many low islands in the Massim. Kwaudi, a man from Tubetube Island, travelled by canoe to Duau to meet his kula partner, Trevor's maternal grandfather. He asked him for help with food, as Duau (the kula region on Normanby Island) has mountains and rivers and did not suffer from a lack of rain. So a large gift of food was prepared, baskets of yams and a large pig, and Trevor's grandfather brought it to Tubetube. This gift of food, called atugalala (literally 'noise made with the lime pot'), was the reason why the bagi named Dilimeyana moved to him. Kwaudi had not yet finished its decorations, but brought it to Duau at a later time. The 
bagi was named after Kwaudi's sister's daughter, Dilimeyana, at his request, as the food had saved the girl's life. In the 1970s, the bagi was halved by a Dobu man and so Dilimeyana 1 and 2, much shorter now, were circulating separately. Dilimeyana 2 is currently hidden and will not be discussed here, but Dilimeyana 1 had an interesting fate, that I was told about in 2015.

This bagi, of the highest rank, was held for 39 years by a man named Austin (now-deceased) on Woodlark Island. The tusk of the large pig that had been part of Trevor's grandfather's gift of food, played a significant role in moving it much later (in December 1994), reminding Austin of the original reason for the bagi's route and justifying Trevor's demand to let it continue its kula travel on its original track. After almost 40 years with Austin, the bagi has now moved on and was on Dobu Island in September 2015, now travelling under the name Dilimeyana 40, held in Mwemweyala Village, waiting for the right mwali, named Tomanuboi, so that it can continue on its path. Dilimeyana 40 and Tomanuboi are regarded as a married couple, longing for each other, wanting to meet on the same route but in travelling in opposite directions (see Kuehling 2012). In fact, it was through Trevor's effort to bring Tomanuboi to Austin that Dilimeyana moved again. Austin died soon after passing Dilimeyana on, and many people told me that this

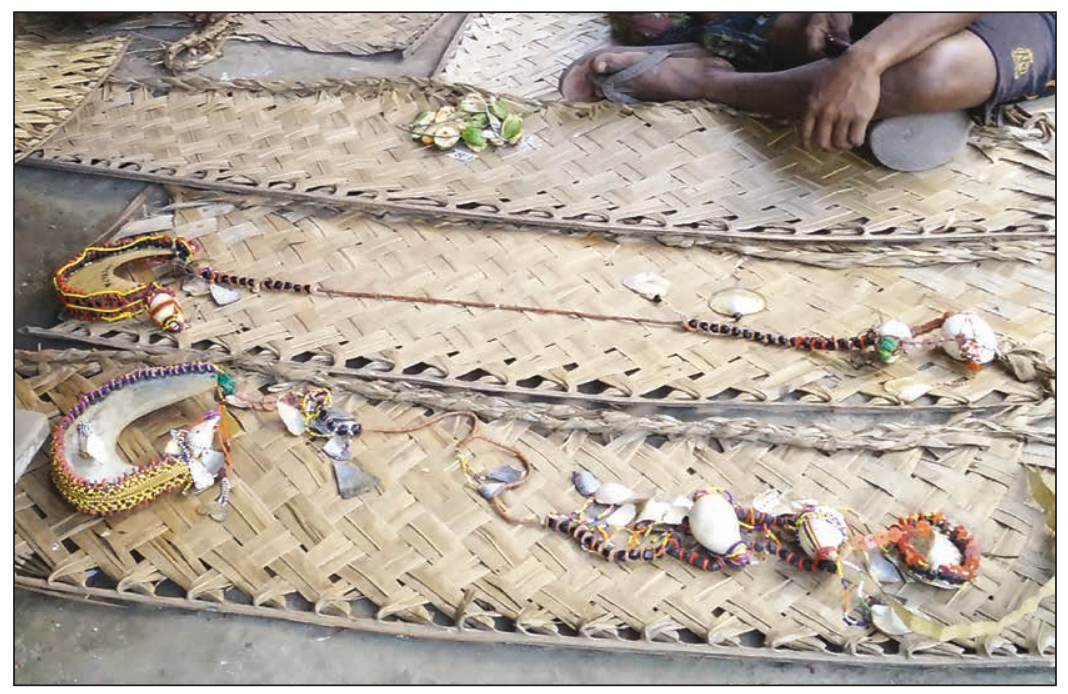

Figure 8. Dilimeyana 40 (front) and Lepoyata 1, two of the highest-ranked bagi. September 2015. Photo by author. 
was his just punishment for holding onto it for so long. As an aside, Damon (2002: 124) writes that the name Dalmeyon is his Woodlark tutor's name, very likely referring to the same bagi. I suspect that this is an example of alternative stories, a very common feature in the histories of kula valuables.

The detailed scheming and complex exchanges required to move Dilimeyana 40 are only known to some people, but the lives that were saved with the original gift of food certainly indicate and justify the high value of this bagi. The large pig (its tusks formed a perfect circle I was told, such as those which used to circulate in kula as doga or dona; see Malinowski 1922: 375), together with baskets of yams were a token of solidarity, of kula partnership at its best. As Dilimeyana 40 moves on, it reminds kula players of the obligations and opportunities that are open only to those who nurture their relationships by visiting, hosting, passing on kula valuables and keeping their promises for future exchanges. Such partnerships are inherited and are among a man's greatest assets. These high-ranking dagula, literally 'feather used as head decoration', are supposed to be inherited within the matrilineage or at least within the clan, but in some cases they are passed on from father to son. If this happens, it causes ripples in the entire circle, as partners mourn the loss of their valuable and work on retrieving it, as Trevor did for Dilimeyana 40. The other half of Dilimeyana is likely hidden because of such a move into a different clan. "The bagi is sick" (bagi i le 'oasaya), as Dobu people say in such a situation.

\section{THE PULSE OF KULA}

As I have outlined above, the movement of bagi and mwali is affected by death, distracted by local events, and halted for decades if a temporary owner decides to wait for the "right" counter-gift. Kula valuables do not move steadily and local events derail even high-ranking bagi and mwali, complicating the future routes that they are supposed to follow. Such "sick" objects can get stuck, as currently is the case with the mwali named Kabisawali that was passed on by a man to his own son, thereby changing its clan-based track. Recently, in 2016, that man died, adding to the long chain of dead bodies related to holding this particular "witchcraft" mwali (Malnic 1998: 47; Annette Weiner in Myers and Kirshenblatt-Gimblett 2001: 299).

There is always a great risk involved in passing on one's kula valuables, as the contingencies of life and death counter the scheming, planning, organising and persuasion work of kula masters. Return gifts may take so many years that two generations are left waiting, deprived of their valuable counter-gift. Today, there are at least 2000 valuables moving in and out of kula exchange, and in and out of local exchanges. The large number of objects in circulation calls for some general remarks, I believe, as from a distance they do form a pattern that can be observed and to some extent anticipated. 


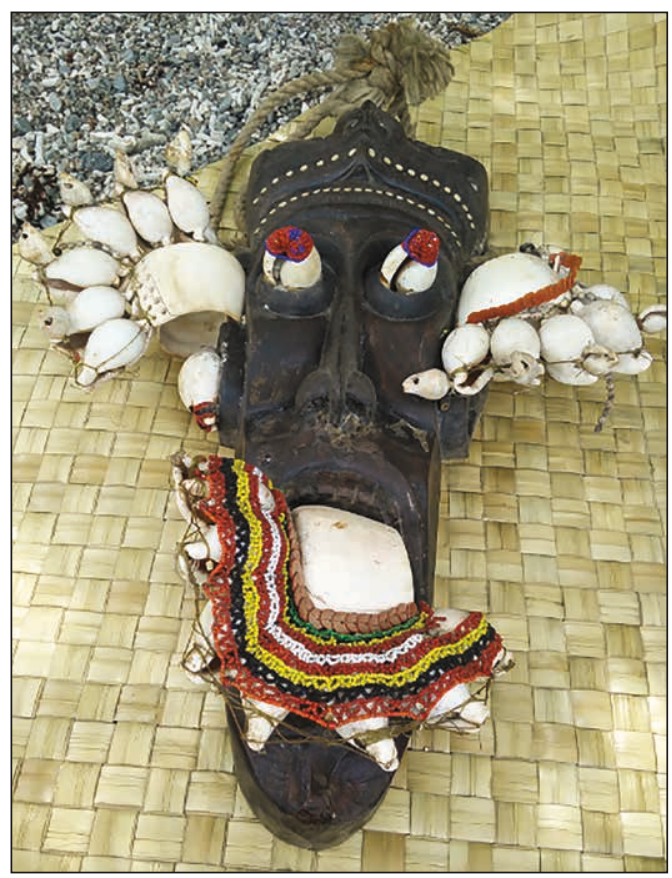

Figure 9. Kabisawali; the mwali shell at the centre is named Teganiu. September 2015. Photo by the author.

High-ranking objects move slowly as a series of preparatory exchanges are required before they change hands (Kuehling 2005: Diagram 13). These gifts are all reciprocated and so it often takes a number of expeditions before a high-ranking bagi or mwali moves. Kula dynamics are driven by the thousands of small objects that attract partners to visit each other, to re-open a kula province after death, to aspire and plan, provide hospitality, and practice magic and rhetoric. The partnerships of most kula participants are not aiming at moving an ornament of the highest rank, yet kula remains one of the most exciting, dangerous and manly things to do. I have argued elsewhere that kula is the only way to go on a vacation (2005: 220), and it is one of the most complex mental exercises. It is not only the desire to compete, to achieve, to gain a name, as Munn (1986) has famously argued, it is also the need for kula objects to deal with the tensions and emotions resulting not only from death, but also from the problems of everyday life. Kula ornaments "solve 
our problems", as a kula master from Duau (Normanby Island) wrote to me in a letter (Fig. 10). Their relevance for today's life in the island region is characterised by his statement that it is "our money".

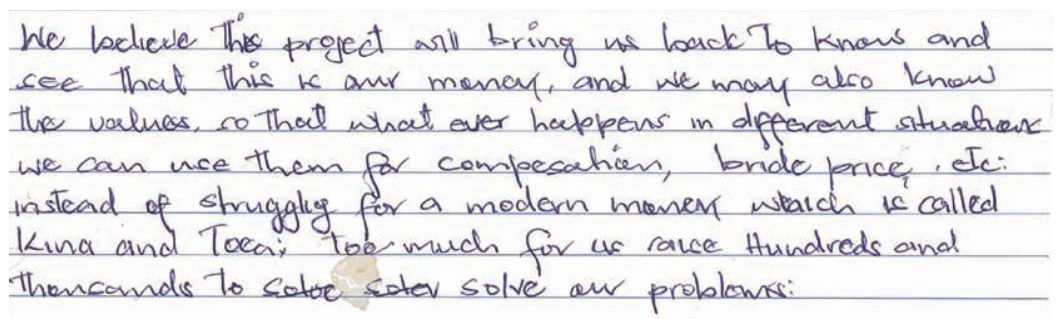

Figure 10. Extract of letter from kula master to the author, March 2013.

The pulse of smaller bagi and mwali rushes through the veins of the kula networks, ulai by ulai, expedition by expedition, moving between 100 and 500 mwali or bagi. Occasionally it pushes the high-ranking objects along, creating fame for the few lucky ones who succeed, who are links in the right chains of partnerships, who are cunning and ruthless enough to attract them, and resilient enough to sustain the competitive reactions of their peers who may enviously plot revenge. To be one of these few is certainly a motivation for the ambitious, risk-taking individual — but most kula participants do not feel competent or courageous enough to go for the "jackpot" and are satisfied with moderate gains. Without these average exchanges, I would argue, kula could not have survived the last century.

$$
\text { *** }
$$

Kula value is based on the notion that bagi and mwali are moved by the flow of life-circle events and empowered by the social values of generosity, selfdiscipline and respect. Practicing kula provides opportunities to learn and to demonstrate one's worthiness to receive precious knowledge, as only the best players are chosen to inherit the paths and objects. For aspiring leaders of matrilineages where top-ranked objects circulate, fame is a product of the object's rank. The names of high-ranking kula objects, and of those persons who circulated them, become legends in local lore, increasing in value while being narrated in time and space, as Munn (1986) has demonstrated so well in The Fame of Gawa.

One of the kula masters from Dobu likened the ranking of bagi and mwali to the fruits of a betel nut palm. The infructescence or "branch" on top, with ripe nuts, is called alana. The ones below are, in descending order, almost ripe, 
unripe, tiny, and at the bottom there are only the flowers. The lower "branches" (pwesisina) are distinguished from the top ones (alana) and it is the same with kula valuables. Their ranking takes place when many kula objects are displayed and sorted according to their value after a group has returned from a kula expedition (tanaleleya), as described above. Most lineages do not belong to the top level circles: "most men will never touch dagula" (Trevor Timoti pers. comm., 2015) and never reach the highest level of fame. He explained that holding those "ripe" bagi and mwali can generate hard feelings that are expected to cause death by sorcery, which only knowledgeable people can deflect. This is why a beginner needs a powerful mentor to survive and build a career as the heir of a top-ranking player. Ideally, the heir is the smartest and best-behaved sister's son, but without a suitable candidate, a man's sister is also a strong contestant to continue the inherited track that follows clan lines around the islands.

Fame, to my understanding, or what Trevor considers social "ripeness", is the reward for being a regular participant in kula expeditions and an excellent host to kula partners, and building a reputation as someone who is trustworthy, generous, intelligent and resourceful. Senior men also find fame by organising successful kula journeys, bringing home a large number of bagi or mwali and losing no participants. Their investments of time and resources, the social skills necessary to see such a group enterprise through with all the required meals and speeches, and the communal memories of such a trip create the leader's "big name" or ale sinabwana. It is through participation in such journeys that most of the skills of kula are transmitted; the prospect of joining such an exciting event works as a pedagogic tool for teenagers who compete for the honour. The aspiration to be picked as the "golden boy" of a kula master reportedly still motivates teenagers to display admirable attitudes, such as obedience, generosity and respect.

Recently netball competitions have been initiated between kula stations, with the aim of providing an introduction into kula during the visits of teams for tournaments. In September 2015, Sawa'edi youth from Fergusson Island visited Vakuta Island for such an event and brought back about two hundred mwali. Various speeches that I heard praised the teenagers for their respectful behavior (alamai 'ita) and explained it as a result of kula values of love and hospitality (oboboma). Methodist pastors in the Massim region strongly support kula, as Jenevieve Sailon, minister of Sanaloa Island, put it: "We can see these youths are better villagers when they engage in kula."

To nurse teenagers' interest in kula, by providing the first-hand experience of a group expedition, is regarded by local leaders as a strategy to ensure that they understand that at home, outside the inter-island kula track, all kula objects are highly valuable, comparable to pigs. On an intimately personal level, the emotional element of personal narratives contributes to their value 
as kitomwa or 'village wealth' (kitoum in Kiriwina), not as official origin stories that list previous exchanges (tetela) but as relational accounts that explain a person's reason for crying when seeing a specific bagi or mwali: "My son is named after this one", "I gave this for my aunt's funeral", "This was used as an engagement gift for so-and-so", etc. Such histories, like the ones concerning gifts of pigs, may be recounted in village courts at times, but they are used as evidence and not to rank the object. Pig skulls or tusks are often kept as mementos, as well as evidence for exchanges of the past, and can dramatically be held up publicly during a mediation; just mentioning the name of a mwali or bagi serves the same purpose, even if the object itself has already moved on. Their value empowers these objects' capacity to bring peace and friendship, to demonstrate moral qualities, to provide travel opportunities and to rationalise death. According to my research, this makes them infinitely valuable to the islanders.

\section{NOTES}

1. Names in this initial story are pseudonyms.

2. These include publications by Damon (1980a, 1980b,1983a, 1983b, 1983c, 1990, 1993, 2000, 2002) for Woodlark (Muyuw) Island; Munn $(1983,1986,1990)$ for Gawa Island; and Campbell (1978, 1983a, 1983b, 2002a, 2002b), Malinowski $(1920,1922,1926,1929,1935)$ and Weiner $(1976,1983,1984,1985,1988$, 1992, 1994) for the Trobriand Islands.

3. These are often misidentified as Spondylus shell (see Liep 1983: 86).

4. I have never seen them worn on the upper arm as documented by Malinowski (1922, plate XVII) because, I was told, the inside of the shell "bites" the biceps when flexed. Moreover, both decoration and rope prevent their use as armbands. They are typically carried by the rope or in a basket.

5. See Kuehling 2012 for a critique of the supposed gender of bagi and mwali.

\section{ACKNOWLEDGEMENTS}

This article was first drafted at the foot of Mount Maunganui in Aotearoa, occasionally gazing at the ocean in search of inspiration. I am grateful for the helpful comments of the anonymous reviewers and wish to thank Judith Huntsman, Melinda Allen and Michael Young for their critique and edits. The islanders of the kula region continue to be the most gracious hosts and co-workers. Without their active support, this research would not be possible. Over the years various institutions have funded my work, especially the Research School of Pacific and Asian Studies of The Australian National University, the University of Regina, and most recently the Canadian Social Science Research Council (SSHRC Grant \#453-2014-2062). 


\section{REFERENCES}

Campbell, Shirley, 1978. Restricted access to knowledge in Vakuta. Canberra Anthropology 1 (3): 1-12.

1983a. Kula in Vakuta: The mechanics of keda. In E. Leach and J.W. Leach (eds), The Kula: New Perspectives on Massim Exchange. Cambridge: Cambridge University Press, pp. 201-27.

-1983b. Attaining rank: A classification of shell valuables. In E. Leach and J.W. Leach (eds), The Kula: New Perspectives on Massim Exchange. Cambridge: Cambridge University Press, pp. 229-48. 2002a. The Art of Kula. Oxford: Berg.

2002b. What's in a name? The search for meaning. In A. Herle, N. Stanley, K. Stevenson and R.L. Welsch (eds.), Pacific Art. Persistence, Change and Meaning. Adelaide: Crawford House, pp. 166-79.

Damon, Frederick H., 1980a. The problem of the Kula on Woodlark Island: Expansion, accumulation, and overproduction. Ethnos 45: 176-201.

1980b. The Kula and generalised exchange: Considering some unconsidered aspects of the elementary structures of kinship. Man (N.S.) 15 (2): 267-92.

-1983a. On the transformation of Muyuw into Woodlark Island: Two minutes in December, 1974. The Journal of Pacific History 18 (1): 35-56.

1983b. What moves the kula: Opening and closing gifts on Woodlark Island. In E. Leach and J.W. Leach (eds), The Kula: New Perspectives on Massim Exchange. Cambridge: Cambridge University Press, pp. 309-42.

1983c. Muyuw kinship and the metamorphosis of gender labour. Man (N.S.) 18 (2): 305-26.

1990. From Muyuw to the Trobriands. Transformations along the Northern Side of the Kula Ring. Tuscon: The University of Arizona Press.

-1993. Representation and experience in Kula and western exchange spheres (or, Billy). Research in Economic Anthropology 14: 235-54.

2000. From regional relations to ethnic groups? The transformation of value relations to property claims in the Kula Ring of Papua New Guinea. Asia Pacific Journal of Anthropology 1 (2): 49-72.

-2002. Kula valuables. The problem of value and the production of names. L'Homme 162: 107-36.

Damon, Frederick H. and Roy Wagner (eds), 1989. Death Rituals and Life in the Societies of the Kula Ring. DeKalb: Northern Illinois Press.

Fortune, Reo F., 1932. Sorcerers of Dobu. The Social Anthropology of the Dobu Islanders of the Western Pacific. London: Routledge and Kegan.

Kuehling, Susanne, 2005. Dobu. Ethics of Exchange on a Massim Island, Papua New Guinea. Honolulu: University of Hawaii Press.

—2012. They spear, hit again, bite, get engaged and sometimes marry: Revisiting the gendering of kula shells. Anthropologica 54 (2): 319-32.

2017. A fat sow called Skulfi: 'Expensive' words in Dobu Island society. In E. Gnecchi-Ruscone and A. Paini (eds), Tides of Innovation. Value, Materiality and Place. Canberra: ANU Press, pp. 193-224. 
Leach, Jerry W. and Edmund Leach (eds), 1983.The Kula. New Perspectives on Massim Exchange. Cambridge: Cambridge University Press.

Liep, John, 1983. A note on shells and kula valuables. In M. Macintyre (comp.), The Kula. A Bibliography. Cambridge: Cambridge University Press, pp. 85-86.

2007. A Papuan Plutocracy. Ranked Exchange on Rossel Island. København: Aarhus University Press.

Macintyre, Martha, 1983a. The Kula. A Bibliography. Cambridge: Cambridge University Press.

-1983b. Changing Paths. An Historical Ethnography of the Traders of Tubetube. Unpublished PhD thesis, Australian National University, Canberra.

Malinowski, Bronislaw, 1920. Kula: The circulating exchange of valuables in the archipelagoes of Eastern New Guinea. Man 20 (July): 97-105.

-1922. Argonauts of the Western Pacific. An Account of Native Enterprise and Adventure in the Archipelagoes of Melanesian New Guinea. London: Routledge and Kegan Paul.

-1926. Crime and Custom in Savage Society. London: Routledge and Kegan Paul. 1929. The Sexual Life of Savages in North-Western Melanesia. London: Routledge and Kegan Paul.

-1935. Coral Gardens and their Magic. London: George Allen and Unwin.

Malnic, Jutta, 1998. Kula: Myth and Magic in the Trobriand Islands. Wahroonga: Cowry Books.

Mauss, Marcel, 1990 [1923-1924]. The Gift. The Form and Reason for Exchange in Archaic Societies. London: Routledge. [Translation by W.D. Halls].

Munn, Nancy D., 1983. Gawan kula: Spatiotemporal control and the symbolism of influence. In E. Leach and J.W. Leach (eds), The Kula: New Perspectives on Massim Exchange. Cambridge: Cambridge University Press, pp. 277-308.

-1986. The Fame of Gawa: A Symbolic Study of Value Transformation in a Massim (PNG) Society. Cambridge: Cambridge University Press.

-1990. Constructing regional worlds in experience: Kula exchange, witchcraft and Gawan local events. Man (N.S.) 25: 1-17.

Myers, Fred R. and Barbara Kirshenblatt-Gimblett, 2001.Art and material culture: A conversation with Annette Weiner. In F.R. Myers (ed.), The Empire of Things. Regimes of Value and Material Culture. Santa Fe: School of American Research Press, pp. 269-313.

Thune, Carl E., 1980. The Rhetoric of Remembrance: Collective Life and Personal Tragedy in Loboda Village. Unpublished PhD thesis, Princeton University.

Weiner, Annette B., 1976. Women of Value, Men of Renown. New Perspectives in Trobriand Exchange. Austin: University of Queensland Press.

- 1983. 'A world of made is not a world of born': Doing kula in Kiriwina. In E. Leach and J.W. Leach (eds), The Kula: New Perspectives on Massim Exchange. Cambridge: Cambridge University Press, pp. 147-70.

1984. From words to objects to magic: "Hard words" and the boundaries of social interaction. In D.L. Brenneis and F.R. Myers (eds), Dangerous Words. New York: New York University Press, pp. 161-91.

1985. Inalienable wealth. American Ethnologist 12 (2): 210-27. 
- 1988. The Trobrianders of Papua New Guinea. New York: Cengage Learning. 1992. Inalienable Possessions: The Paradox of Keeping-While-Giving. Berkeley: University of California Press.

1994. Cultural difference and the density of objects. American Ethnologist 21 (2): 391-403.

\begin{abstract}
This paper examines the value of kula objects by focusing on the perspectives of islanders from the southern kula region. By linking kula practice to death and life, I argue that the objects' value is complex: material, sentimental and personal, created by partnerships in time and space. Kula valuables are valuable because they are managed by the most respected elders, occupy the minds of the those considered the most intelligent people of the region, and serve to build relationships, as well as test the honesty and integrity of individuals. They are also valued for their capacity to provide hospitality and solidarity, to repair conflicts and to express love and grief.
\end{abstract}

Keywords: Kula Ring valuables, accumulated histories, kula exchange, material culture, Dobu Island, Papua New Guinea

\title{
CITATION AND AUTHOR CONTACT DETAILS
}

Kuehling, ${ }^{1}$ Susanne, 2017. "We die for kula"-An object-centred view of motivations and strategies in gift exchange. Journal of the Polynesian Society 126 (2): 2.181-208; DOI:http://dx.doi.org/10.15286/jps.126.2.181-208

${ }^{1}$ Contact details: Department of Anthropology, University of Regina, 3737 Wascana Parkway, Regina, SK, S4S0A2, Canada. Email: Susanne.kuehling@gmail.com 
